\title{
SEPARATION AND CLEANING AS A MAIN PROCESS IN THE SUSTAINABLEFARM
}

\author{
MarianPANASIEWICZ ${ }^{1}$, Pawel SOBCZAK ${ }^{1}$, Jacek MAZUR ${ }^{\mathbf{1}}$, \\ Kazimierz ZAWIŚLAK ${ }^{1}$, Wioletta ŻUKIEWICZ-SOBCZAK ${ }^{2}$, Yuri FATYKHOV ${ }^{3}$ \\ ${ }^{1}$ Department of Food Engineering and Machines, University of Life Sciences in Lublin, POLAND \\ ${ }^{2}$ Pope John Paul II State School of Higher Education in Biała Podlaska, Department of Public Health, \\ Regional Center Research of Environment, Agriculture and Innovative Technology EKO-AGRO-TECH, \\ POLAND \\ ${ }^{3}$ Kaliningrad State Technical University, Mechanics and Technology Faculty, RUSSIA \\ E-mail of the corresponding author: marian.panasiewicz@up.lublin.pl
}

Keywords:organization, cleaning, separation, sustainable farm, physical properties

\begin{abstract}
The paper presents the results of a study on evaluation of a selected group of physical properties of dry mixtures of juniper in relation to the process of their cleaning and separation using two types of cleaning separators. It has been shown that the course and the effectiveness of the process of separation of juniper berry-like cones from a dry mixture depends on the recognition of certain physical properties of the mixture as well as the type and parameters of the used separator devices. In addition, the most important geometric and dimensional characteristics of particular fractions obtained in the process of separation and cleaning of the mixture were specified.
\end{abstract}

\section{INTRODUCTION}

Common juniper(Juniperuscommunis $l$.) is a shrub, more rarely a tree with variable height and form. It occurs in central and southern Europe, Asia Minor, northern parts of Asia, Africa and in North America. In the food, pharmaceutical and cosmetic industries juniper berry-like cones are used in ground form or asextracts or as essential oils. To a lesser extent essential oils obtained from the needles and twigs are also used. Berry-like cones of common juniper are obtained from specimens growing in the wild, and hence plantations of this plant are not established. The content of essential oil varies depending on the origin of the raw material, the amount of sunshine, as well as climatic and soil conditions and it ranges from $0.7-0.8 \%$ in immature fruits to $2.85 \%$ in the berries harvested in warm and dry mountain areas. The berry-like cones with the highest content of essential oils are used as spice and raw material for the gin production, while those of inferior quality are designated to produce cosmetic oil and for pharmaceutical industry (Kozłowska 2002,Horabik 2001, Lorestani et al. 2012, Ożarowska et al. 1989, Tylek et al. 2002, Kuźnicka et al. 1987). Cosmetic industry adapted both fruits and essential oils obtained from juniper as valuable resources - they are ingredient of tonics, aftershave lotions, air fresheners, insect repellents, and as an important component of perfumes, both for men and women. Juniper wood is also known and appreciated - high content of essential oils deter pests. Temples were built of it and in wealthier homes there were wardrobes and boxes, which repelled tineid moths. Today the wood and its aromatic properties are used in food industry - the most expensive and the best cuts of meats and cold cuts are smoked in juniper smoke. The main final raw material are juniper berry-like cones that have to be separated and cleaned after harvest using sieve-pneumatic or vibratory separators (Dmitrewski 1981, Sobczak et al. 2012, Jurga 1997). Sieve separation is based on one of the basic characteristics for separating heterogeneous mixtures viz. geometric features such as thickness, width and length. The procedure relies on passing of the separated material through a single or a set of sieves of varied construction or shape of the holes under the two conditions determining the separation of 
a mixture - the separation will take place only when the dimension of the sieve holes lies within the range of the variation in the width or thickness of the particles present in the mixture, and there is a movement of the mixture on sieve compliant with the principles allowing the fine particles to fall into the holes (Mazur et al. 2013, Krakowski 1997, Kośmicki et al. 1993, Dmitrewski et al. 1981). Pneumatic separation, besides the sieve one, is the cleaning method most commonly used in food industry. The process of separation takes place thanks to the air stream that is the factor causing the appearance of the differences in the aerodynamic characteristics of particles composing mixtures. By implementing a singular or multiple air streams it is possible to separate the raw material in terms of quality, as well as geometry, density and mass properties (Panasiewicz et al. 2012, Kośmicki et al. 1993, Krakowski 1997, Tylek 2003).

\section{THE AIM AND SCOPE OF THE RESEARCH}

The aim and tasks of the research concerned the detailed designation and assessment of selected groups of physical properties of dry granular mixture from which the juniper berry-like cones were separated. In addition, it was also to determine the geometric and mass characteristics of juniper berry-like cones in the context of juniper cleaning process and effective separation of all contaminants and other components undesirable from the technological point of view. The scope of work included the process of separation and cleaning of juniper berry-like cones performed on two laboratory separating and cleaning devices.

\section{MATERIALS AND METHODS}

Research material consisted of dried mixtures of juniper cones together with impurities collected from their natural environment using pneumatic devices, and then dried in convection drying process. Such mixtures along the desired, most valuable fractions such as juniper berry-like cones contained also a variety of organic and inorganic contaminants. Contaminations of biological origin were separated from the dried mixture; these included remains of damaged fruits, thicker needles, and pieces of twigs, as well as fine dusty debris created probably during the drying process and storage.

The division into dimension-based fractions was done using two sets of research stands, i.e. a SZ-1 laboratory sifter fitted with a set of sieves with round openings and drive providing back-and-forth motion and a laboratory vibratory sieve shaker RETSCH AS200 with variable acceleration caused by adjustable amplitude of vibration. Measurement and determination of selected properties were carried out taking into account the capability of smooth adjustment of the parameters of the cleaning and separation process (fig. 1). During the tests the moisture of the mixture and its tapped and bulk density were determined as well as the tipping and pouring angles and the granular composition. 

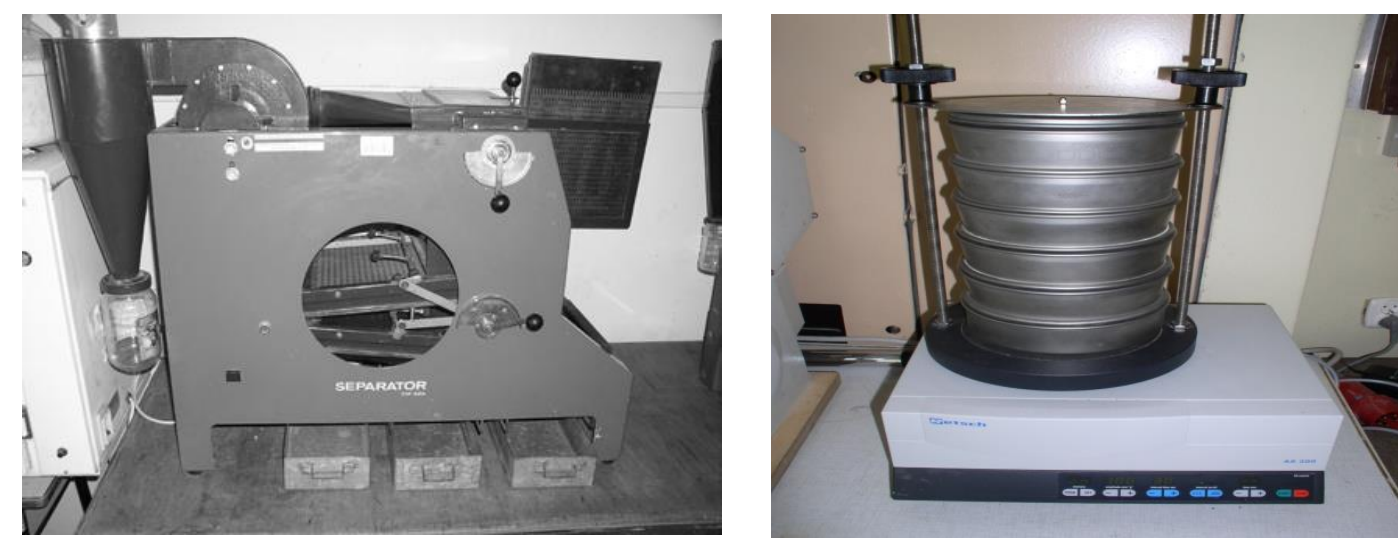

Fig. 1 Research stands for the determination of physical properties and conducting the process of separation and cleaning: pneumatic sieve sifter of SZ-1 type; laboratory vibratory sieve shaker RETSCH AS200.

\section{RESULTS}

The determination of physical properties of the individual components of the mixture was preceded by dividing them into size fractions. From the content of each particular fraction, the majority of which consisted of various impurities and unusable waste, the primary raw material was separated that constitutes the most valuable part of the processed undergrowth. Using the differentiationin the dimensions and shape of the particles of eachfraction their moisture content as well as geometric and mass characteristics were determined. And so the average water content in the mixture (debris, berry-like cones) was $0.063\left[\mathrm{~kg} / \mathrm{kg} \mathrm{s}^{-1}\right]$. This confirms the correct preparation for and completion of the convection drying process of the mixture after it had beenharvested. The average bulk and tapped densities of the material prepared for the research were $0.357 \mathrm{~g} \mathrm{~cm}^{-3}$ and 5.02 $\mathrm{g} \mathrm{cm}^{-3}$ respectively. In the case of tipping angle, its lowest value for clean juniper berrylike cones was obtained for the size fraction $\geq 500 \mu \mathrm{m}$ and 100-200 $\mu \mathrm{m}$. This was respectively 24 and 52 degrees. Lack of contamination in these fractions of the mixture significantly eased dumping of berry-like cones with the shape close to spherical. A slightly greater angle of repose (56 degrees) was recorded for the fraction of debris, with identified tendency of a decrease in this value with the increase of particle size. The highest value of tipping and pouring angle was recorded in the case of the fraction containing juniper needles. By comparing the results of these parameters for particular fractions of the mixture, it must be stated that the debris and needle significantly increase the value of the tipping angle hindering the movement of berry-like cones on an inclined surface. The results of granular distribution of mixture of dried juniper cones obtained in the course of separation on two types of separators are presented in table 1 and 2.

Due to their dimensions, juniper berry-like cones remained on the upper screens of the vibratory sieve shaker having the mesh size of 5 and $4 \mathrm{~mm}$. However, it was noted that during the separation process dry berry-like cones had been damaged by the metal wire sieves. This resulted in damaged scales passing through to smaller size fractions thus reducing the quality of the berry-like cones. 
Table 1. The results of granular distribution of dried juniper cones mixture obtained on vibratory sieve shaker Retsch AS 200.

\begin{tabular}{|l|c|c|c|c|c|c|}
\hline \multirow{3}{*}{ Fraction } & \multicolumn{9}{|c|}{ RETSCH AS 200 } \\
\cline { 2 - 7 } & \multicolumn{2}{|c|}{ I } & \multicolumn{2}{|c|}{ II } & \multicolumn{2}{c|}{ III } \\
\cline { 2 - 7 } & Mass [g] & Percentage & Mass [g] & Percentage & Mass [g] & Percentage \\
\hline$>500 \mu \mathrm{m}$ & 37.244 & 37.25 & 24.143 & 24.26 & 35.834 & 36.00 \\
\hline $400-500 \mu \mathrm{m}$ & 8.831 & 8.83 & 4.954 & 4.98 & 7.766 & 7.80 \\
\hline $315-400 \mu \mathrm{m}$ & 1.92 & 1.92 & 2.016 & 2.03 & 2.294 & 2.30 \\
\hline $200-315 \mu \mathrm{m}$ & 9.846 & 9.85 & 8.437 & 8.48 & 9.166 & 9.21 \\
\hline $100-200 \mu \mathrm{m}$ & 12.247 & 12.25 & 12.878 & 12.94 & 12.457 & 12.52 \\
\hline $50-100 \mu \mathrm{m}$ & 18.69 & 18.69 & 26.348 & 26.48 & 18.452 & 18.54 \\
\hline$<50 \mu \mathrm{m}$ & 11.222 & 11.22 & 20.723 & 20.83 & 13.567 & 13.63 \\
\hline Total & 100 & 100 & 99.499 & 100 & 99.536 & 100 \\
\hline
\end{tabular}

Table 2. The results of granular distribution of dried juniper cones mixture obtained on sifter SZ-1.

\begin{tabular}{|c|c|c|c|c|c|c|}
\hline \multirow{3}{*}{ Fraction } & \multicolumn{6}{|c|}{ SZ-1 } \\
\hline & \multicolumn{2}{|r|}{$\mathrm{I}$} & \multicolumn{2}{|c|}{ II } & \multicolumn{2}{|c|}{ III } \\
\hline & Mass [g] & Percentage & Mass [g] & Percentage & Mass [g] & Percentage \\
\hline$>500 \mu \mathrm{m}$ & 45.860 & 46.33 & 46.210 & 46.58 & 43.070 & 43.39 \\
\hline $400-500 \mu \mathrm{m}$ & 2.630 & 2.66 & 2.010 & 2.03 & 3.210 & 3.23 \\
\hline $315-400 \mu \mathrm{m}$ & 0.500 & 0.51 & 0.320 & 0.32 & 0.700 & 0.71 \\
\hline $200-315 \mu \mathrm{m}$ & 3.150 & 3.18 & 4.110 & 4.14 & 4.210 & 4.24 \\
\hline $100-200 \mu \mathrm{m}$ & 11.649 & 11.77 & 11.800 & 11.89 & 10.830 & 10.91 \\
\hline $50-100 \mu \mathrm{m}$ & 24.000 & 24.25 & 21.730 & 21.90 & 22.030 & 22.19 \\
\hline$<50 \mu \mathrm{m}$ & 11.197 & 11.31 & 13.030 & 13.13 & 15.220 & 15.33 \\
\hline Total & 98.985 & 100 & 99.210 & 100 & 99.270 & 100 \\
\hline
\end{tabular}

From the stand point of the technological relevance the implementation of the pneumatic sieve sifter produced much better outcome. In this case, the light pollution and mostly the needles were effectively separated, and most of them ended up in the size fractions of a mesh size smaller than $1 \mathrm{~mm}$. The effectiveness of the separation of clean juniper berrylike cones from the mixture in the case of the sifter SZ-1 equalled to $48.07 \%$, while in the case of the vibratory sieve shaker it was $39.71 \%$.

\section{DISCUSSION AND CONCLUSIONS}

As demonstrated by the analysis of the test results an effective (100\%) separation of impurities from the tested sample of dry mixture of forest undergrowth rendered very difficult. A significant number and amount of particular contaminants was characterised by properties very similar to the characteristics of the base species, and therefore was difficult to separate be it on the stand with pneumatic sieve sifter or the one with vibratory sieve shaker. This leads to a concussion that a mixture of undergrowth requires a special technological approach and the use of often peculiar and unconventional assembly of separating and cleaning machines. Moreover, when compared with cleaning cereal grains and seeds, the cleaning process requires to a greater extent the implementation of multiple repetitions (cycles) of the cleaning procedure, which increases the total duration of the process and its energy consumption. 
Additionally, from the stand point of pneumatic separation, identification of selected group of physical properties of both the fraction of the base raw material, and the fraction of contaminants was a very important stage of this research. The obtained results of research and the analysis thereof provided a valuable database and practical insights that should be taken into account when carrying out cleaning and separation into size fractions of this group of raw materials. The determined data regarding the characteristics of mixtures may be used as guidelines in setting up the parameters of the cleaning and separation processes in industry.

\section{REFERENCES}

Dmitrewski J., Gach S., Roszkowski H., Waszkiewicz C., (1981). Elementy teorii i obliczania maszyn czyszczących oraz urządzeń suszarniczych. SGGW, Warszawa

Horabik J., (2001). Charakterystyka właściwości fizycznych roślinnych materiałów sypkich istotnych w procesach składowania. Acta Agrophisica, 54, ISSN 1234-4125.

Jurga R., (1997) Podstawy teoretyczne procesu czarnego czyszczenia ziarna. Cz.1. Przegl. Zboż.-Młyn., 41, 45-47.

Kośmicki Z., Kęska W., Feder S., (1993). Próba klasyfikacji przemian fizykomechanicznych materiałów, przerabianych przez maszyny rolnicze dla potrzeb projektowania tych maszyn. Zesz. Probl. Post. Nauk Rol., 408, 71-76.

Kozłowska J., (2002). Rośliny bogate w barwniki oraz ich znaczenie i zastosowanie. Cz. I. Wiadomości zielarskie, 5, 9-12.

Krakowski R.,(1997). Inżynieria i aparatura przemysłu spożywczego. Skrypt AR Wrocław.

Kuźnicka B., Dziak M., (1987). Zioła i ich zastosowanie. Historia i współczesność. Państwowy Zakład Wydawnictw Lekarskich. Warszawa.

Lorestani A. N., Rabani H., Khazaei Y., (2012). Design and construction of an automatic coefficient of friction measuring device. Agric. Eng. Int. CIGR Journal, 14, 1, 120-124.

Mazur J., Panasiewicz M., Zawiślak K., Sobczak P., Kobus Z., Nadulski R. (2013). Ocena zanieczyszczeń występujących przy zbiorze mechanicznym wybranego runa leśnego. Inżynieria Rolnicza, 1(141), 131-135.

Ożarowska A., Jaroniewski W., (1989). Rośliny lecznicze i ich praktyczne zastosowanie. Instytut Wydawniczy Związków Zawodowych. Warszawa.

Panasiewicz M., Sobczak P., Mazur j., Zawiślak K., Andrejko D. (2012). The technique and analysis of the process of separation and cleaning grain materials. Journal of Food Engineering, 109, 603-608.

Sobczak P., Zawiślak K., Panasiewicz M., Mazur J., Piekarski D. (2012). Wpływ wyboru sita na proces separacji okrywy nasion rzepaku w separatorze pneumatyczno-sitowym. Acta Agrophysica, 19 (1), 133141.

Tylek P. (2003). Kształt jako cecha rozdzielcza nasion. Inżynieria Rolnicza, 11(53), 213-222.

Tylek P., Walczyk J., (2002). Separator pneumatyczny do nasion drzew leśnych. Przegląd Techniki Rolniczej i Leśnej, 10, 16-25. 